\title{
SELF-CONSOLIDATION AND SURFACE MODIFICATION OF MECHANICAL ALLOYED Ti-25.0 AT.\% Al POWDER MIXTURE BY USING AN ELECTRO-DISCHARGE TECHNIQUE
}

\begin{abstract}
Electrical discharges using a capacitance of $450 \mu \mathrm{F}$ at $0.5,1.0$, and $1.5 \mathrm{~kJ}$ input energies were applied in a $\mathrm{N}_{2}$ atmosphere to obtain the mechanical alloyed $\mathrm{Ti}_{3} \mathrm{Al}$ powder without applying any external pressure. A solid bulk of nanostructured $\mathrm{Ti}_{3} \mathrm{Al}$ was obtained as short as $160 \mu \mathrm{sec}$ by the Electrical discharge. At the same time, the surface has been modified into the form of Ti and Al nitrides due to the diffusion process of nitrogen to the surface. The input energy was found to be the most important parameter to affect the formation of a solid core and surface chemistry of the compact.

Keywords: Sintering, Mechanical alloying, Powder consolidation, Intermetallic compounds, Titanium aluminide
\end{abstract}

\section{Introduction}

Syntheses of intermetallic compounds with high melting points via mechanical alloying have been attempted in numerous studies $[1,2]$. In general, combustion reactions have been initiated by ball-milling in a variety of highly exothermic reaction mixtures. In general, combustion reactions have been initiated by ball-milling in a variety of highly exothermic reaction mixtures. The formation of intermetallics from their elemental components accelerates during ball-milling to become a self-sustaining high temperature reaction $[3,4]$. Among intermetallic compounds, the titanium aluminide compounds $\left(\mathrm{Ti}_{3} \mathrm{Al}, \mathrm{TiAl}\right.$ and $\left.\mathrm{TiAl}_{3}\right)$ are attractive candidate materials for aerospace structure and engine applications [5]. The advantages of these materials are their low density, high specific strength, and relatively good properties at elevated temperatures and high creep resistance [6,7].

Conventionally, a solid bulk typed $\mathrm{Ti}_{3} \mathrm{Al}$ can be synthesized by reacting mixed stochiometric powders of $\mathrm{Ti}$ and $\mathrm{Al}$ at higher temperature or arc melting of $\mathrm{Ti}$ and $\mathrm{Al}$ pieces $[8,9]$. In spite of their research significance, in recent years there have been relatively few studies on the consolidation of $\mathrm{Ti}_{3} \mathrm{Al}$ in the form of powder. The usual sequence in powder metallurgy (PM) operations is to compact a metal powder in a die at room temperature and subsequently sinter it at elevated temperatures. Not only are high pressure, high temperature, and long times required, but in the case of reactive materials, such as Ti and its alloys, an inert atmosphere is also inevitably required. The high temperatures involved in these processes, however, result in detrimental changes in the microstructure and mechanical properties. Recently, PM allows the use of ultrafine structured powders produced using various processes such as high energy mechanical milling and rapid solidification $[10,11]$.

Compared to the conventional high temperature sintering, spark plasma sintering (SPS) has shown a considerable reduction times in the sintering processing. It is a rapid densification process which has the potential to minimize grain growth by enhancing sinterability through dielectric breakdown of an oxide film between powder particle surfaces and rapid heating [12]. SPS was found to compact intermetallic compounds satisfactorily through the simultaneous application of direct current pulses of high intensity and uniaxial pressure. Several results had already reported the properties of bulk TiAl intermetallic based alloys with an ultrafine structure by using SPS [13-16]. However, the surface modification of intermetallic compound compact can not be obtained by using SPS process.

Lee and co-workers have developed the electro-dischargesintering (EDS) process, which has more advantages compared to SPS in terms of sintering time and energy efficiency [17-19]. In this paper, it is first reported that a solid bulk of nanostructured $\mathrm{Ti}_{3} \mathrm{Al}$ can be made in times of $160 \mu \mathrm{sec}$ by EDS and at the same time, the surface can be modified into the form of titanium and aluminum nitrides.

\section{Experimental}

Mechanical alloying (MA) was performed using a high speed mixer/mill and a cylindrical partially stabilized zirconia

\footnotetext{
* KOREA AEROSPACE UNIVERSITY, DEPARTMENT OF MATERIALS ENGINEERING, GOYANG-SI 10510, KOREA

** FACULTY OF NANOTECHNOLOGY AND ADVANCED MATERIALS ENGINEERING, SEJONG UNIVERSITY, SEOUL 05000, KOREA

*** WONKWANG HEALTH SCIENCE UNIVERSITY, DEPARTMENT OF DENTAL LABORATORY, IKSAN 54538, KOREA

**** UIDUK UNIVERSITY, DIVISION OF GREEN ENERGY ENGINEERING, KYEONGJU 38004, KOREA

\# Corresponding author: whlee@sejong.ac.kr
} 
(PSZ) vial (60 $\mathrm{mm}$ in inner diameter and $87 \mathrm{~mm}$ long). Elemental $\mathrm{Ti}$ and $\mathrm{Al}$ powders, and high $\mathrm{Cr}$ hardened steel balls $(10.0 \mathrm{~mm}$ and $4.7 \mathrm{~mm}$ in diameter) were placed in the vial in an Ar-flushed glove box to avoid oxidation. The mean powder particle size of both as-received $\mathrm{Ti}$ and $\mathrm{Al}$ was $45.0 \mu \mathrm{m}$, and the purity of the powders was better than $99.95 \%$. As-received $\mathrm{Ti}$ and $\mathrm{Al}$ powders were pre-milled for the uniform mixing at $130 \mathrm{rpm}$ for $300 \mathrm{~min}$ using the same mixer/mill before applying a high energy ballmilling procedure. The mass of the powder charge was $15 \mathrm{~g}$ and the mass ratio of ball to powder was 10:1. The charged atomic ratio of the reactants corresponded to the reaction stoichiometry (Ti-25.0 at.\% Al). High energy ball-milling at 500 rpm was carried out for 4,8 , and 13 hours.

0.3 gram of mechanical alloyed (MA) powder was vibrated into a quartz tube with an inner diameter of $4.0 \mathrm{~mm}$ that had a tungsten electrode at the bottom. An upper electrode was automatically machined-driven on the top of the powder column. A capacitor bank of $450 \mu \mathrm{F}$ was charged with three different electrical input energies $(0.5,1.0$, and $1.5 \mathrm{~kJ})$. The discharge chamber was evacuated to $2 \times 10^{-3}$ torr and then filled with $\mathrm{N}_{2}$ gas up to 350 torr. The charged capacitor bank instantaneously discharged through the powder column by on/off high vacuum switch which closes the discharge circuit. The overall consolidation process by the discharge is referred to as electro-dischargesintering (EDS). A schematic of the EDS apparatus is shown in (Fig. 1). For the comparison, MA powders were cold-pressed by applying 10 tons of uniaxially directional press and the resulting pellet with $8 \mathrm{~mm}$ in a diameter was sintered at $1250^{\circ} \mathrm{C}$ in a vacuum of $2 \times 10^{-7}$ torr for two and half hours.

(a)

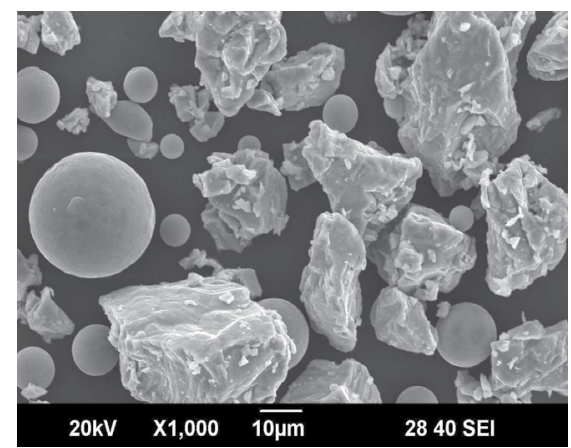

(c)

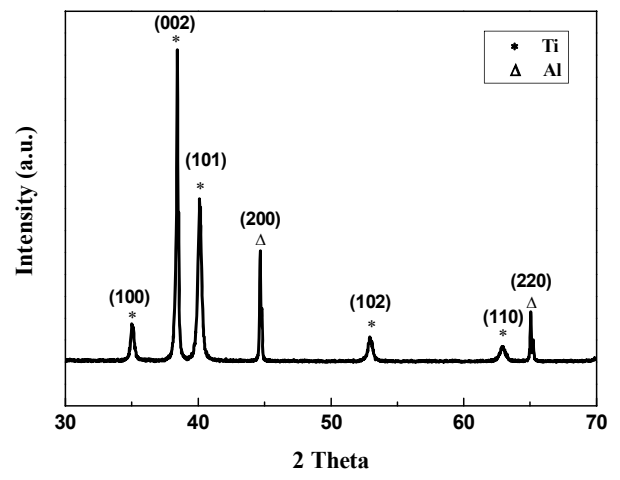

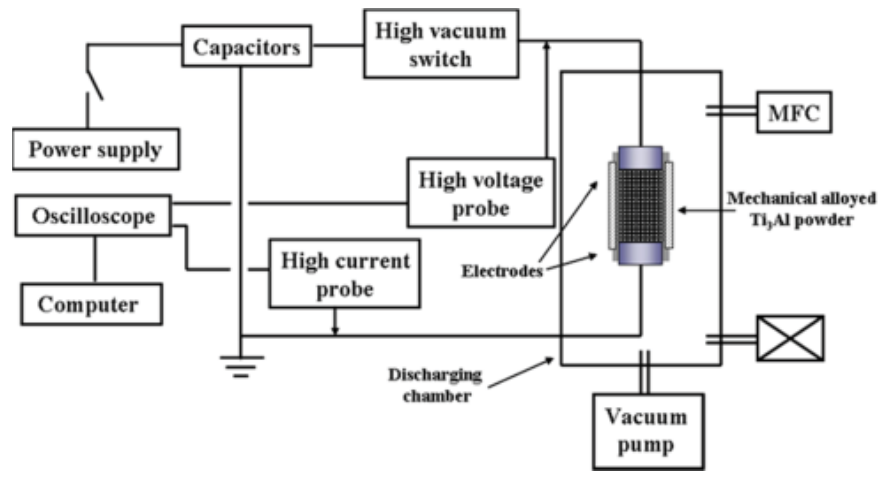

Fig. 1. A schematic diagram of the experimental apparatus developed for electro-discharge-sintering (EDS)MA powders and their consolidated compacts by EDS without any surface treatment were examined by XPS (X-ray photoelectron microscopy). The phase compositions of them were investigated by X-ray diffraction (XRD) using $\mathrm{Cu} \mathrm{K} \alpha$ radiation. They were also examined under scanning electron microscopy (SEM) and transmission electron microscopy (TEM).

\section{Results and discussion}

Figs. $2 \mathrm{a}$ and $2 \mathrm{~b}$ show SEM micrographs of the reactant Ti25.0 at.\% $\mathrm{Al}$ powder mixture before and after the pre-milling, respectively. Pre-milling at $130 \mathrm{rpm}$ for 5 hours leads to more uniform distribution of reactant powders in terms of their size and shape without any phase transformation occurred as confirmed by XRD (Figs. 2c,d). After pre-milling at 130 rpm for 5 hours,

(b)

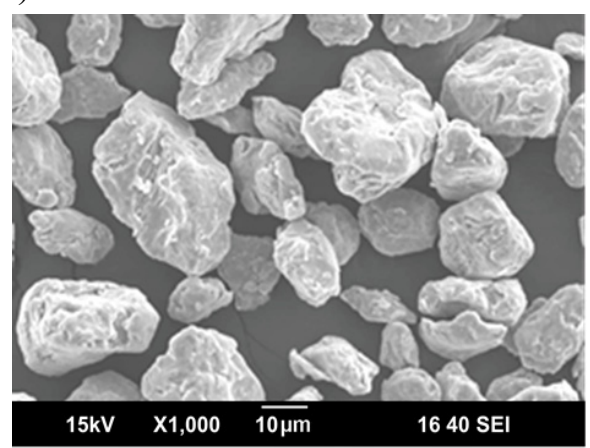

(d)

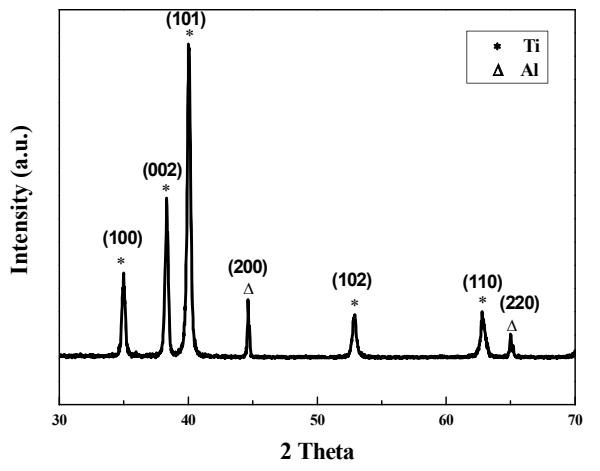

Fig. 2. SEM micrographs of the Ti-25.0 at.\% Al powder mixture (a) before and (b) after pre-milling, and XRD patterns of the powder mixture (c) before and (d) after pre-milling at $130 \mathrm{rpm}$ for 5 hours 
(a)

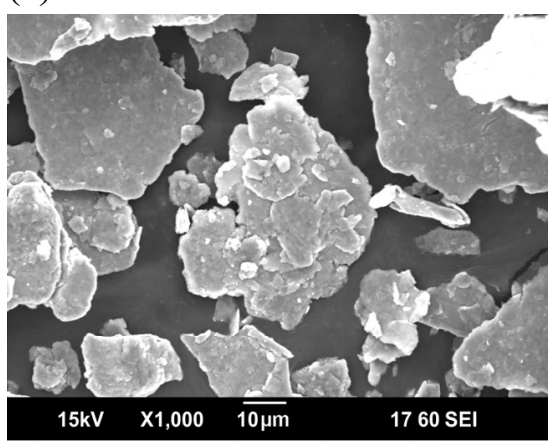

(b)

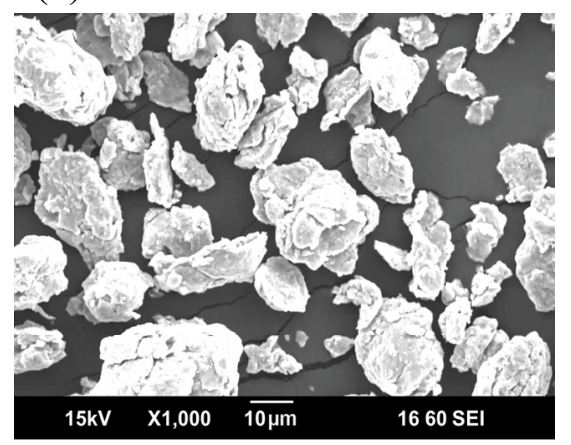

(c)

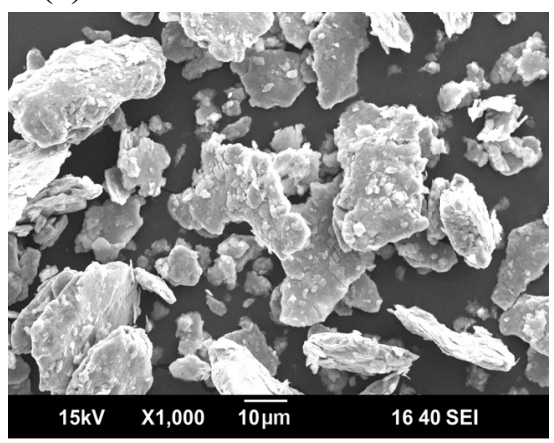

Fig. 3. SEM micrographs of the Ti-25.0 at.\% Al powder mixture mechanical alloyed for (a) 4, (b) 8, and (c) 13 hours

the intensity of $\mathrm{Ti}$ (101) peak increased compared to $\mathrm{Ti}(002)$, which is possible to be attributed to the strain energy stored in the Ti powder during a milling process.

SEM micrographs of the MA Ti-25.0 at.\% Al powders at various milling times are shown in (Fig. 3). At the early stage of milling, MA Ti and Al powders tend to agglomerate each other and form somewhat flake shape with an average size of about $80 \mu \mathrm{m}$. The shape becomes round with the size of about $25 \mu \mathrm{m}$ as milling time approaches to 8 hours. After 13 hours milling, the MA powders are getting bigger up to $60 \mu \mathrm{m}$. XRD patterns of the powder mixture of MA at $500 \mathrm{rpm}$ as a function of milling times are shown in (Fig. 4), indicating a complete transformation to the intermetallic powder of $\mathrm{Ti}_{3} \mathrm{Al}$ after 8 hours milling.

The $\mathrm{MA} \mathrm{Ti}_{3} \mathrm{Al}$ powders were consolidated by a conventional high temperature sintering process as described in the section of Experimental. As shown in (Fig. 5a), the sintering process produced the $\mathrm{Ti}_{3} \mathrm{Al}$ compact in a porous nature. Its average grain size is found to be about $25 \mu \mathrm{m}$. The cross section view of the electro-discharge-sintered $\mathrm{Ti}_{3} \mathrm{Al}$ compact which was discharged

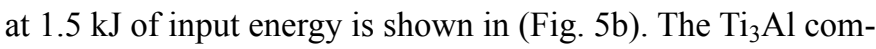
pact is composed of powder particles that were deformed and completely welded together by the discharge, providing a totally bulk nature. Fig. 6 shows a TEM image of the electro-dischargesintered $\mathrm{Ti}_{3} \mathrm{Al}$ compact discharged at input energy of $1.5 \mathrm{~kJ}$. The average crystallite size is about $100-350 \mathrm{~nm}$. Moreover, the morphology of the grain boundary is quite facet, suggesting that the grain boundaries are quite stable.

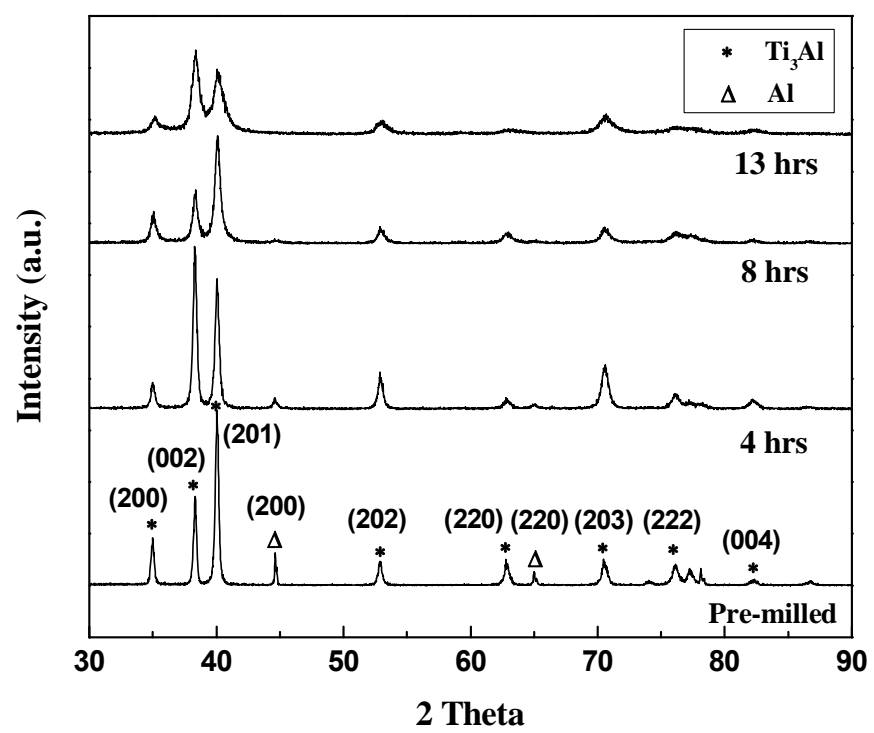

Fig. 4. XRD patterns of mechanical alloyed Ti-25.0 at. $\% \mathrm{Al}$ powder mixture as a function of milling times

To investigate the surface chemical states of both asreceived powder mixture and the electro-discharge-sintered $\mathrm{Ti}_{3} \mathrm{Al}$ compact, XPS was carried out. (Fig. 7a) shows narrow scan spectra of the Ti $2 p$ region for as-received Ti powder and electro-discharge-sintered $\mathrm{Ti}_{3} \mathrm{Al}$ compacts. A Ti $2 \mathrm{p}_{3 / 2}$ peak at $458.5 \mathrm{eV}$ is shown, with $5.8 \mathrm{eV}$ splitting between the Ti $2 \mathrm{p}_{1 / 2}$ and Ti $2 \mathrm{p}_{3 / 2}$ peaks. Thus, the surface of as-received Ti powder (a)

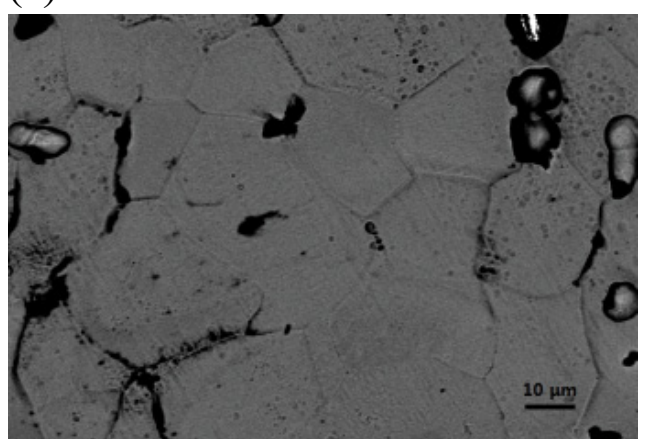

(b)

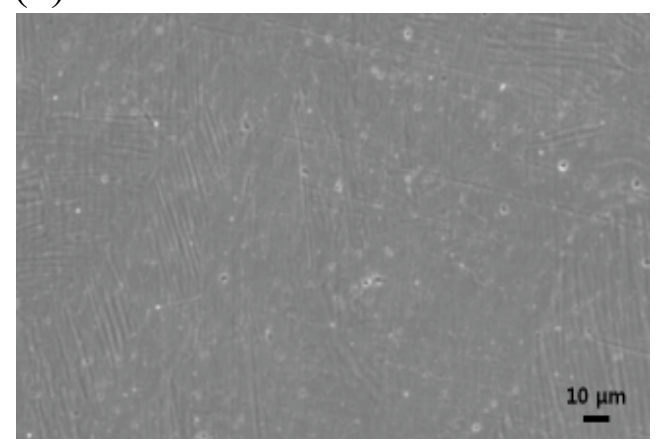

Fig. 5. SEM micrographs of the cross-sections of the consolidated $\mathrm{Ti}_{3} \mathrm{Al}$ compacts obtained (a) by conventional sintering at $1250{ }^{\circ} \mathrm{C}$ in a vacuum of $2 \times 10^{-7}$ torr for 2.5 hours, and (b) by electro-discharge-sintering at input energy of $1.5 \mathrm{~kJ}$ 


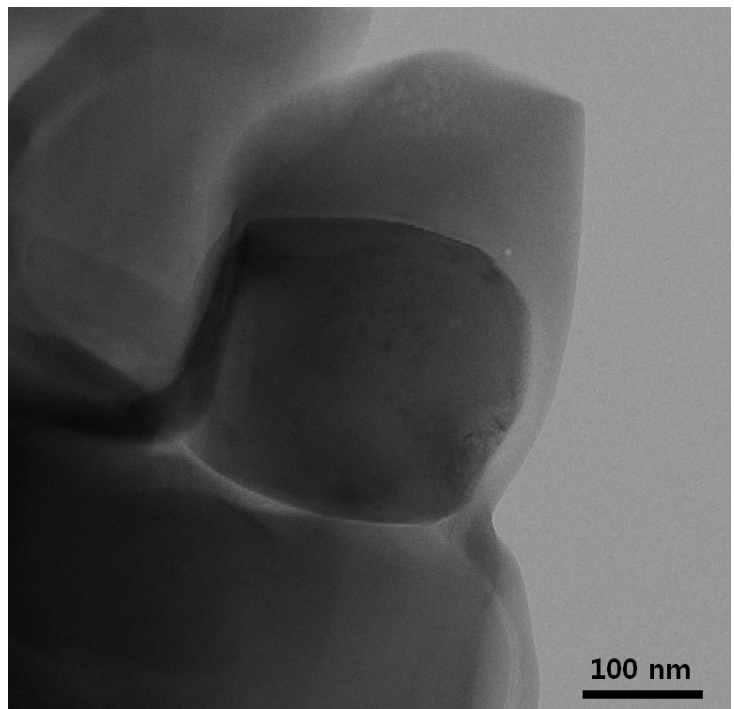

Fig. 6. TEM bright-field image of electro-discharge-sintered $\mathrm{Ti}_{3} \mathrm{Al}$ compact at input energy of $1.5 \mathrm{~kJ}$

(a)

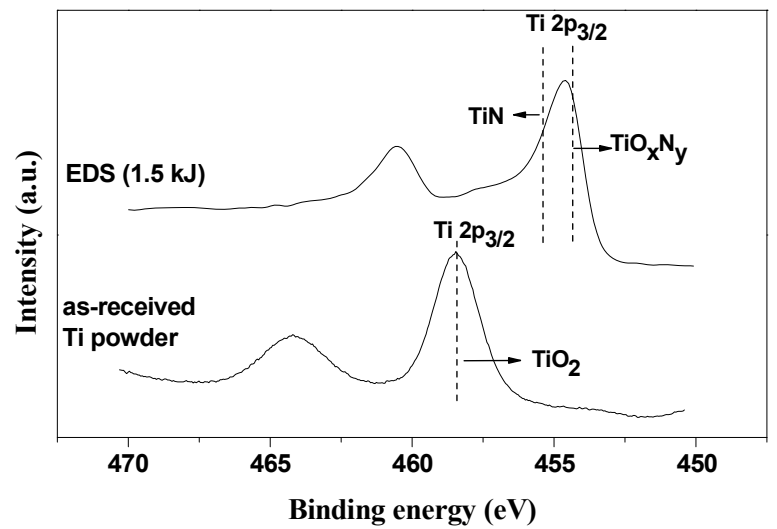

is primarily in the form of $\mathrm{TiO}_{2}$ [20-22]. However, electrodischarge-sintered $\mathrm{Ti}_{3} \mathrm{Al}$ compact discharged at $1.5 \mathrm{~kJ}$ of input energy showed a Ti $2 \mathrm{p}_{3 / 2}$ peak at $454.5 \mathrm{eV}$, with $5.8 \mathrm{eV}$ splitting between the Ti $2 p_{1 / 2}$ and Ti $2 p_{3 / 2}$ peaks. Therefore, the surface is primarily in the combined form of Ti nitride and Ti oxynitride. It can thus be known that EDS process using a sufficient input energy can successfully modify the original surface from $\mathrm{TiO}_{2}$ into Ti nitrides in less than $160 \mu \mathrm{sec}$. This result can be ascribed to EDS breaking down the oxide film of the as-received Ti powder. Then, the fresh metallic surface of the compact subsequently reacted mainly with nitrogen, forming Ti nitrides during the electrical discharge process.

Narrow scan spectra of the $\mathrm{Al} 2 \mathrm{p}$ region for as-received Al powder and electro-discharge-sintered compacts are shown in (Fig. 7b). The maximum was positioned at about $74.4 \mathrm{eV}$. Thus, the surface of as-received $\mathrm{Al}$ powder is primarily in the form of $\mathrm{Al}_{2} \mathrm{O}_{3}$. Electro-discharge-sintered $\mathrm{Ti}_{3} \mathrm{Al}$ compact discharged at $1.5 \mathrm{~kJ}$ of input energy showed the $\mathrm{Al} 2 \mathrm{p}$ at $74.4 \mathrm{eV}$ with a shoul-

(b)

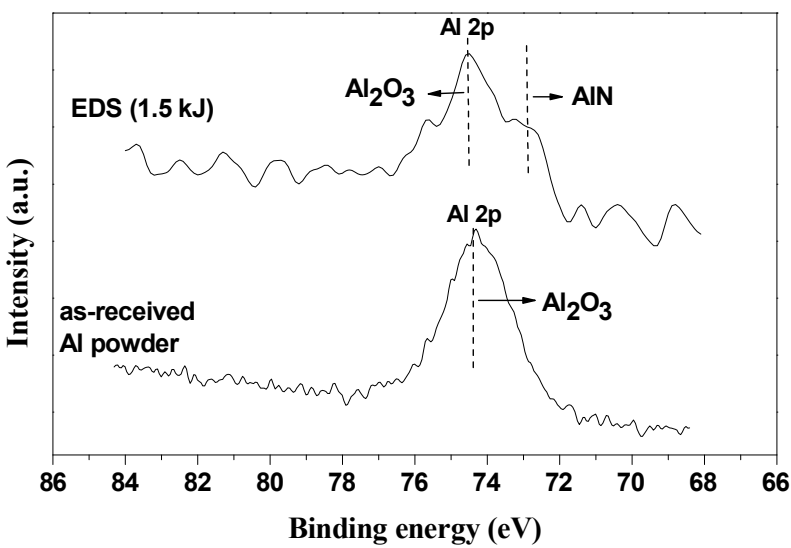

Fig. 7. XPS high resolution spectra of the (a) Ti $2 \mathrm{p}$ and (b) $\mathrm{Al} 2 \mathrm{p}$ regions for as-received elemental powders and electro-discharge-sintered $\mathrm{Ti}_{3} \mathrm{Al}$ compacts measured at input energy of $1.5 \mathrm{~kJ}$

der region at about $73.0 \mathrm{eV}$ which corresponds to AlN [23,24]. It is known that the electro-discharge-sintered $\mathrm{Ti}_{3} \mathrm{Al}$ compact contains the lightly nitride surface.

It is therefore concluded that the electro-discharge-sintering of mechanical alloyed $\mathrm{Ti}_{3} \mathrm{Al}$ powders can produce a solid bulk of nanostructured $\mathrm{Ti}_{3} \mathrm{Al}$ with simultaneous surface modification in times as short as $160 \mu \mathrm{sec}$.

\section{Conclusions}

$\mathrm{Ti}_{3} \mathrm{Al}$ powders were produced by a high-energy ball-milling of elemental Ti and $\mathrm{Al}$ powder mixtures. Electrical discharges of mechanical alloyed $\mathrm{Ti}_{3} \mathrm{Al}$ powder using a capacitance of $450 \mu \mathrm{F}$ as $\mathrm{s}$ function of input energies were carried out without applying any external pressure. The $\mathrm{Ti}_{3} \mathrm{Al}$ powder was successfully consolidated into a solid bulk of $\mathrm{Ti}_{3} \mathrm{Al}$ compact with nano-sized crystallites in $160 \mu \mathrm{sec}$. At the same time, the surface has been modified into the forms of Ti and $\mathrm{Al}$ nitrides due to the diffusion process of nitrogen to the surface. EDS can thus be expected to provide the cost reduction and low energy requirement for combining both sintering and surface modification.

\section{REFERENCES}

[1] K. Kasraee, A. Tayebifard, E. Salahi, J. Mater. Eng. Perfom. 22, 3742 (2013).

[2] S. Sabooni, F. Karimzadeh, M.H. Abbasi, Bull. Mater. Sci. 35, 439 (2012).

[3] J.J. Shon, Metals Mater. 3, 199 (1997).

[4] A.K. Vasudevan, J.J. Petrovic, Mater. Sci. Eng. A 155, 1 (1992).

[5] N. Forouzanmelu, F. Karimzadeh, H. Enayati, J. Alloys Comp. 471, 93 (2009).

[6] A. Couret, G. Molenat, J. Galy, M. Thomas, Intermetallics 16, 1134 (2008). 
[7] P. Bhattacharya, P. Bellon, R.S. Averback, S.J. Hales, J. Alloys Comp. 368, 187 (2004).

[8] M. Zha, H.Y. Wang, S.T. Li, S.L. Li, Q.L. Guan, Q.C. Jiang, Mater. Chem. Phys. 114, 709 (2009)

[9] B.R. Krueger, A.H. Mutz, T. Vreeland, Metall. Trans. A 23, 55 (1992).

[10] D.J. Im, Y.M. Kim, Y.K. Hong, S.J. Park, J. Korea Powder Metall. Inst. 21, 256 (2014).

[11] S.H. Yang, W.Y. Kim, M.S. Kim, Intermetallics 11, 849 (2003).

[12] R. Orru, R. Licheri, A.M. Locci, A. Cincotti, G. Cao, Mater. Sci. Eng. R 63, 127 (2009).

[13] H.A. Calderon, V. Garibay-Febles, M. Umemoto, M. Yamaguchi, Mater. Sci. Eng. A 329, 196 (2002).

[14] H.B. Yu, D.L. Zhang, Y.Y. Chen, P. Cao, B. Gabbitas, J. Alloys Comp. 474, 105 (2009).

[15] S.L. Xiao, J. Tian, L.J. Xu, Y.Y. Chen, H.B. Yu, J.C. Han, Trans. Nonferrous Met. Soc. China 19, 1423 (2009).
[16] S.L. Xiao, L.J. Xu, Y.Y. Chen, H.B. Yu, Trans. Nonferrous Met. Soc. China 22, 1086 (2012).

[17] Y.J. Jo, Y.H. Kim, Y.H. Jo, J.G. Seong, S.Y. Chang, C.J. Van Tyne, W.H. Lee, J. NanoSci. Nanotechnol. 14, 8429 (2014).

[18] Y.J. Jo, Y.H. Kim, Y.H. Jo, J.G. Seong, S.Y. Chang, P.J. Reucroft, S.B. Kim, W.H. Lee, Metals Mater. Int. 21, 337 (2015).

[19] W.H. Lee, Y.J. Jo, Y.H. Kim, Y.H. Jo, J.G. Seong, C.J. Van Tyne, S.Y. Chang, Arch. Metall. Mater. 60, 1185 (2015).

[20] Y.J. Jo, Y.H. Kim, Y.H. Jo, J.G. Seong, Y.K. Ko, S.B. Kim, S.Y. Chang, W.H. Lee, Metals Mater. Int. 21, 159 (2015).

[21] Y.J. Jo, Y.H. Jo, J.G. Seong, Y.H. Kim, S.Y. Chang, M.S. Noh, H.G. Jeong, W.H. Lee, Surf. Eng. 31, 885 (2015).

[22] Y.J. Jo, Y.H. Jo, J.G. Seong, Y.H. Kim, S.Y. Chang, W.H. Lee, Mater. Sci. Technol. 31, 989 (2015).

[23] G. Greczynski, L. Hultman, Applied Surf. Sci. 387, 294 (2016).

[24] P. Motamedi, K. Cadien, Applied Surf. Sci. 315, 104 (2014). 